\title{
Genetics of osteoarthritis
}

\author{
Flavia M Cicuttini, Tim D Spector
}

Osteoarthritis is the most frequent cause of musculoskeletal disability in developed countries. The multifactorial nature of osteoarthritis is well recognised, with a number of environmental risk factors such as obesity, ${ }^{1-3}$ previous injury, ${ }^{45}$ and meniscectomy ${ }^{6}$ strongly associated with the development of osteoarthritis. The role of genetic factors in the development of osteoarthritis has received considerable attention, aided by the rapidly expanding knowledge of molecular biology.

For over 50 years a strong genetic component to certain forms of osteoarthritis has been believed to be present. Early studies by Stecher in $1941^{7}$ showed that Heberden's nodes of the fingers were three times as common in the sisters of 64 affected subjects as in the general population. They concluded that these lesions were inherited as a single autosomal dominant gene with a strong female predominance. Family studies performed in the early 1960s in the United Kingdom on 20 male and 32 female probands with generalised osteoarthritis suggested that first degree relatives were twice as likely also to have radiographic generalised disease. ${ }^{8}$ Subsequent studies provided additional evidence for the familial occurrence of Heberden's and Bouchard's nodes and of degenerative arthritis involving multiple joints. ${ }^{9-11}$ In a study of 391 cases of osteoarthritis, 120 patients, largely middle aged women, were identified to as having a polyarthritis characterised by signs of inflammation and an acute inset of symptoms. Twenty per cent of these patients gave a family history of similar joint disease. ${ }^{12}$ This and other studies suggested a polygenic form of inheritance rather than a single gene defect. ${ }^{1314}$

The most common form of inherited osteoarthritis is primary generalised osteoarthritis. ${ }^{15}$ A genetic predisposition has been suggested by the association with the HLA-A1B8 ${ }^{16}$ and HLA-B8 ${ }^{17}$ haplotypes and with $\alpha 1$ antitrypsin isoform patterns, ${ }^{18}$ although not all studies found this association. ${ }^{1920} \mathrm{~A}$ second type of inherited osteoarthritis is associated with familial calcium pyrophosphate deposition disease (CPDD), which is characterised by the deposition of calcium containing crystals in joint tissue, leading to arthritis-like symptoms. Early onset CPDD has been described in several large families in which the disease progresses to severe degenerative osteoarthritis. ${ }^{21} 22$ In these families, an autosomal dominant mode of inheritance is observed, with an age at onset between the second and fifth decades of life. ${ }^{2122}$ A familial form of osteoarthritis with prominent ocular involvement is the Sickler syndrome, also known as the hereditary arthro-ophthalmopathy. ${ }^{23}$ This syndrome is a relatively common autosomal dominant disease ( 1 in 10000 ) characterised by vitreous degeneration, retinal detachment, and premature degenerative joint disease. Several forms of familial osteoarthritis associated with chondrodysplasia are also have an autosomal dominant pattern of inheritance. ${ }^{24}$

The nature of the genetic influence in osteoarthritis is speculative and may involve either a structural defect (that is, collagen), alterations in cartilage or bone metabolism, or alternatively a genetic influence on a known risk factor for osteoarthritis such as obesity. Certain similarities exist with another common disease of old age, osteoporosis, the trait for bone density having an estimated heritability of $70-90 \%$. Direct comparison is difficult, however, given the vastly superior methodology of bone densitometry compared to radiographs. Proposed candidate genes in the inheritance of osteoarthritis are the collagen genes which encode the most abundant proteins in the cartilage, with type II collagen being the most abundant. There are several reasons to suggest that the failure of the collagenous component of articular cartilage may be responsible for the degeneration of joint tissue in osteoarthritis. First, collagen is the main component of the organic matrix of articular cartilage and plays an important role in the maintenance of the biomechanical properties of cartilage. ${ }^{25}$ Second, the normal assembly of cartilage collagen serves as a mechanical constraint to prevent the expansion of the highly hydrated proteoglycans into the large hydrodynamic domains that are characteristic of proteoglycans free in solution. ${ }^{26} \mathrm{~A}$ failure of this would result in increased hydration of the tissue, softening of the matrix, and cartilage degradation. Third, it has become apparent in recent years that articular cartilage contains a remarkable degree of molecular complexity with regard to the number of biochemical species of collagen. ${ }^{27}$

Genetic linkage analysis of large kindred populations were performed to examine the involvement of candidate genes in inheritable osteoarthritis. Two reports on three unrelated families showed co-inheritance with primary
Guys' and St
Trust, London
SE1 7EH

T D Spector 
generalised osteoarthritis with specific alleles of the gene for type II pro-collagen (COL2A1) on chromosome $12 .^{2829}$ This allele has now been cloned and found to be normal except for a single base mutation at position 519 of the 1 (II) chain ${ }^{30}$ which was found in all affected members of a family but in none of the unaffected or unrelated individuals. A further study of generalised familial disease found that two out of seven families had the mutation, both of which had evidence of an associated chondrodysplasia. ${ }^{31} \quad$ Linkage between COL2A1 and the development of osteoarthritis has now been demonstrated in several families. ${ }^{32}{ }^{33}$ Linkage analysis of several Stickler syndrome kindred has shown that the disease is linked to COL2A1 in approximately a quarter to one half of families. ${ }^{34}$ No clear linkage has been shown in CPDD. However, in a recent study of a large New England family with early onset CPDD and severe degenerative osteoarthritis, ${ }^{36}$ a genetic linkage was found between the disease in this family and chromosome $8 \mathrm{q}$, suggesting that a defective gene at this location may be responsible.

Although the available studies provide conclusive evidence that mutations in COL2A1 are present in affected individuals from some families displaying the phenotype of primary generalised osteoarthritis and mild spondyloepiphyseal dysplasia, other studies have shown that COL2A1 is not the disease locus in other families with osteoarthritis. ${ }^{37}$ Primary generalised osteoarthritis may be a heterogeneous disease at the genetic level and mutations in genes other than COL2A1 may be responsible for the occurrence of this phenotype. For example, yet to be explored is the role of mutations in the genes encoding the minor collagen types (eg, IX, X, XI). Transgenic mouse models with a central deletion in the al chain of the type IX collagen gene suggest that this gene may be important. ${ }^{38}$ Mice homozygous for the transgene have a mild chondrodysplastic syndrome with dwarfism, spinal involvement, and opthalmopathy. In contrast, heterozygotes develop osteoarthritis with no signs of chondrodysplasia. ${ }^{38}$ The role of the other extra cellular matrix proteins will also need to be investigated. For example, it is now feasible to test for osteoarthritis linkage to such candidate genes as aggrecan, decorin, and the link protein. ${ }^{39}$

There is currently little evidence that the common forms of osteoarthritis are due to collagen mutations. The families identified are extremely rare and associated with mild chondrodysplasias. The small number of family studies do not allow clear conclusions to be drawn on the overall contribution of genetics to disease in the population. A recent study used gene specific highly polymorphic markers and affected sibling pair analyses to investigate genetic linkage between generalised osteoarthritis (GOA) and three cartilage matrix genes: COL2A1 which encodes type II collagen, CRTL1 which encodes the cartilage link protein, and CRTM which encodes the cartilage matrix protein. ${ }^{40}$ The analyses showed no linkage between GOA and the three genes in the 38 sibling pairs examined. These results suggest that COL2A1, CRTL1, and CRTM are not major susceptibility loci for GOA. A recent study analysed blood leucocyte DNA to detect mutations in the gene for COL2A1 in patients with cartilage diseases ranging from early onset familial osteoarthritis to lethal chondrodysplasias. ${ }^{41}$ Using the procedure developed for analysis of the COL2A1 gene, mutations were detected in only $2 \%$ of patients with early onset familial osteoarthritis. Although these percentages are minimum estimates because all possible mutations in the gene cannot be detected with this procedure, this still suggests that only a low proportion of osteoarthritis can be explained by this genetic abnormality. Recently, promising new data have suggested an association between polymorphisms of the vitamin $\mathrm{D}$ receptorwhich has recently been associated with osteoporosis-and early knee osteoarthritis. ${ }^{42}$ As some evidence suggests an inverse association between these two common condition, ${ }^{43-45}$ it may be that some polymorphisms of this gene may offer protection against osteoarthritis. This will need to be tested in larger studies.

Recently, a clear genetic influence was shown using 500 unselected female twins aged 45-70 years who were screened radiologically for osteoarthritis of the hands and knees. ${ }^{46}$ The correlations of osteoarthritis disease status were consistently twofold higher in 130 pairs of identical compared to non-identical twins. The influence of genetic factors was estimated to be between $39 \%$ and $65 \%$, independent of known environmental or demographic confounding variables. This genetic effect was consistent whichever radiographic diagnosis of osteoarthritis was used (that is, osteophyte or narrowing) and whether it was defined clinically as knee pain or Heberden's nodes. Both the tibiofemoral and patellofemoral joints of the knee had a genetic influence; only the proximal interphalangeal joints failed to show a genetic effect.

The available evidence suggests that genetic factors have a major role in osteoarthritis. This genetic influence has now been estimated to be up to $65 \%$ in a recent twin study. Exciting work has shown that mutations in the collagen type 2 are important in some rare, familial forms of osteoarthritis. Further work is needed to isolate the gene or genes involved in the pathogenesis of this common, disabling condition.

\section{Summary}

The available evidence suggests that genetic factors have a major role in osteoarthritis. It has been believed for over 50 years that a strong genetic component to certain forms of osteoarthritis is present. This genetic influence has now been estimated to be up to $65 \%$ in a recent twin study. The nature of the genetic influence in osteoarthritis is speculative and may involve either a structural defect (that is, collagen), alterations in cartilage or bone metabolism, or alternatively a genetic influence on a known risk factor for osteoarthritis such as obesity. Exciting work has showed that 
mutations in the collagen type 2 are important in some rare, familial forms of osteoarthritis. Further work is needed on isolating the gene or genes involved in the pathogenesis of this common, disabling condition.

1 Felson DT, Anderson JJ, Naimark A, Walker AM, Meenan RF. Obesity and knee osteoarthritis. The Framingham Study. Ann Intern Med 1988;109:18-24.

2 Anderson J, Felson DT. Factors associated with osteoarthritis of the knee in the first national health and nutrition examination survey (NHANES I). Am $\mathcal{f}$ Epidemiol examination survey

3 Hart DJ, Spector TD. The relationship of obesity, fat distribution and osteoarthritis in women in the general population: the Chingford Study. F Rheumatol 1993;20:331-5.

4 Kellgren JH, Lawrence JS. Osteoarthritis and disk degeneration in an urban population. Ann Rheum Dis 1958;17:38896.

5 Felson DT, Naimark A, Anderson J, Kazis L, Castelli W, Meenan RF. The prevalence of knee osteoarthritis in the elderly. The Framingham Osteoarthritis study. Arthritis Rheum 1987;30:914-8.

6 Cooper C, McAlindon T, Snow S, Vines K, Young P, Kirwan J, Dieppe P. Mechanical and constitutional factors for symptomatic knee osteoarthritis: differences between tol 1994;21:307-13.

7 7. Stecher RM. Heberden's nodes. Heredity in hypertrophic arthritis of the finger joints. $A m$ f Med Sci 1941;201:801.

8 Kellgren JH, Lawrence JS, Bier F. Genetic factors in generalised osteoarthritis. Ann Rheum Dis 1963;22:237-55.

9 Allison AC, Blumberg BS. Familial osteoarthropathy of the fingers. F Bone foint Surg Br 1958;40:538-40.

10 Buchanan WW, Park WM. Primary generalized osteoarthritis: definition and uniformity. $\mathcal{F}$ R heumatol $1983 ; 10$ (suppl 9):4-6.

11 Crain DC. Interphalangeal osteoarthritis characterized by painful inflammatory episodes resulting in deformity of the proximal and distal articulations. $\mathscr{F} A M A$ 1961; 175:1049-51.

12 Kellgren JH, Lawrence JS, Bier F. Genetic factors in generalized osteoarthritis. Ann Rheum Dis 1963;22:237.

13 Lawrence JS. Rheumatism in populations. London: Heinemann, 1977.

14 Lawrence JS, Gelsthorpe K, Morell G. Herberden's nodes and HIA markers in generalised osteoarthritis. $\mathcal{F}$ Rheumatol Suppl 1983;9:32-3.

15 Harper $P$, Nuki G. Genetic factors in osteoarthritis. In, Nuki $\mathrm{G}$, ed. The aetiopathogeneis of osteoarthritis. Tunbridge Wells: Pitman, 1980:184-201.

16 Pattrick M,Manhire A, Ward M, Doherty M. HLA-A, B antigens and al-antitrypsin phenotypes in nodal and generalized osteoarthritis and erosive osteoarthritis. Ann Rheum Dis 1989;48:470-5.

17 Brodsky T, Appelboam A, Govaerts Famey JP. Antigens HLA et nodosites d'Herbeden. Acta Rheumatol 1979; 3:95-103.

18 Pattrick M, Manhire A, Ward AM, Doherty M. HLA-AB antigens and $\alpha 1$-antitrypsin phenotypes in nodal generalized osteoarthritis and erosive arthritis. Ann Rheum Dis ized osteoarthricis

19 Ercilla MG, Brancos MA, Breysse G, Breysse Y. HLA antigens in Forestier's disease, ankylosing spondylitis, and polyarthrosis of the hands. $\mathcal{F}$ Rheumatol 1977;4(suppl 3):89-93.

20 Benavides G, Cerantes A, Silva B, Kantona G, Lardizabal J. HIA and Herbeden's nodes in Mexican mestizos. Clin Rheumatol 1985;4:97-8.

21 Ryan LM, McCarty DJ. Calcium pyrosphosphate crystal deposition disease: pseudogout; articular chondrocalcinosis. In: McCarty DJ, Koopman WJ, eds. Arthritis and allied conditions, 12th ed. Philadelphia: Lea and Febiger, conditions, 12 1993:1835-55.

22 Zitnan D, Sitaj S. Chondrocalcinosis polyarticularis (familiaris). Radiol Diagn (Berl) 1960;1:498-500.

23 Stickler GB, Belau PG, Farrell FJ, Hayles AC. Hereditary progressive arthroophthalmopathy. Mayo Clin Proc 1965; 40:433-5.

24 Zitnan D, Sitaj S. Chondroarticularis. I. Clinical and radiologic study. Ann Rheum Dis 1963;22:142-69.
25 Kempson GE, Mir H, Swanson SAV, et al. Correlations between stifffness and the chemical constituents of cartilage on the human femoral head. Biochim Biophys Acta cartilage on the hur

26 Urban J, Maroudas A, Bayliss MT, Dillon J. Swelling pressure of proteoglycans at the concentrations found in cartilaginous tissues. Biorheology 1979;16:447-64.

27 Mayne R. Cartilage collagens: what is their function, and are they involved in articular disease? Arthritis Rheum 1989;32:241-6.

28 Palotie A, Vaisanen P, Ott J, Ryhanen L, Elima K, Vikkula $M$, et al. Predisposition to familial osteoarthritis linked to type II collagen gene. Lancet 1989;i:924-7.

29 Knowlton RG, Katzenstein PL, Moscovitz RW, Weaver EJ, Malemud CJ, Pathria MN, et al. Genetic linkage of a polymorphism in the type II procollagen gene (Col 2A1) to primary osteoarthritis associated with mild chondrodysplasia. N Engl f Med 1990;322:526-30.

30 Alla-Kokko L, Baldwin CT, Moskovitz RW, Prockop DJ. A single base mutation in the type II procollagen gene (COL2A1) as cause of primary osteoarthritis associated with a mild chondrodysplasia. Proc Natl Acad Sci USA 1990;87:6565-8.

31 Pun YL, Moskowitz RW, Lie S, Sundstrom WR, Block SR, McEwen C, et al. Clinical correlations of osteoarthritis associated with a single-base mutation (Argenine 519 to cysteine) in type II procollagen gene. Arthritis Rheum 1994;37:264-9.

32 Hull R, Pope FM. Osteoarthritis and cartilage collagen genes (letter). Lancet 1989;ii:1337-8.

33 Vikkula M, Palotie A, Ritvaniemi P, Ott J, Ala-Kokko L, Sievers, et al. Early onset osteoarthritis linked to the type II procollagen gene; detailed clinical phenotype and further analysis of the gene. Arthritis Rheum 1993;36:401-9.

34 Francomano CA, Liberfarb RM, Hirose T, Streeton EA, Meyers DA, Pyeritz RE, et al. The Stickler syndrome: evidence for the close linkage to the structural gene for type II collagen. Genomics 1987;1:293-6.

35 Knowlton RG, Weaver EJ, Struyk AF, Knobloch WH, King $\mathrm{RA}$, Norris $\mathrm{K}$, et al. Genetic linkage analysis of hereditary arthro-opthalmopathy (Stickler syndrome) and the type II procollagen gene. Am f Hum Genet 1989;45:681-8.

36 Baldwin CT, Farrer LA, Adair R, Dharmavaram R, Jimenez $S$, Anderson L. Linkage of early-onset osteoarthritis and chondrocalcinosis to human chromosome 8q. Am $\mathcal{F ~ H u m ~}$ Genet 1995;56:692-7.

37 Williams CJ, Jimenez SA. Heritable diseases of cartilage caused by mutations in collagen genes. F Rheumatol Suppl 1995;43:28-33

38 Nakata K, Ono K, Miyazaki J, Olsen BR, Muragaki Y, Adach $\mathrm{E}$, et al. Osteoarthritis associated with mi chondrodysplasia in transgenic mice expressing $\alpha 1$ (IX) collagen
chains with a central deletion. Proc Natl Acad Sci USA 1993;90:2870-4.

39 Rimoin DL, Rasmussen IM, Briggs MD, Roughley PJ, Gruber HE, Warman ML, et al. A large family with features of pseudoachondroplasia and multiple epiphyseal dysplasia: exclusion of seven candidate gene loci that encode proteins of the cartilage extracellular matrix. Hum Genet 1994; of the cartilag

40 Loughlin J, Irven C, Fergusson C, Sykes B. Sibling pair analysis shows no linkage of generalized osteoarthritis to the loci encoding type II collagen, cartilage link protein or cartilage matrix protein. $B r \mathcal{F}$ Rheumatol 1994;33:1103-6.

41 Ritvaniemi P, Korkko J, Bonaventure J, Vikkula $M$, Hyland $\mathrm{J}$, Paassilta $\mathrm{P}$, et al. Identification of COL $2 \mathrm{Al}$ gene mutations in patients with chondrodysplasias and familial ostetions in patients with chondrodysplasias and fam

42 Griffiths GO, Keen RW, Hart DJ, Lanchburg JS, Doyle DV, Spector TD. Polymorphisms of the vitamin D receptor in early knee osteoarthritis. Br $f$ Rheumatol 1996;35 (suppl 1):117

43 Cooper C, Cook PL, Osmond C, Fisher L, Cawley MI. Osteoarthritis of the hip and osteoporosis ofthe proximal femur. Ann Rheum Dis 1991;50:540-2.

44 Hart DJ, Mootoosamy I, Doyle DV, Spector TD. The relationship between osteoarthritis end osteoporosis in the general population: the Chingford Study. Ann Rheum Dis 1994;53:158-62.

45 Dequeker J, Johnell O. Osteoarthritis protects against femoral neck fracture: the MEDOS study experience. Bone 1993;14(suppl 1):S51-6.

46 Spector TD, Cicuttini F, Baker J, Hart DJ. Genetic influences on osteoarthritis: a twin study $B M \mathcal{F}$ (in press). 